(Sao Paulo). 68 Suppl 1:27-34.

2. Glina S, Fragoso JB, Martins FG, Soares JB, Galuppo AG, Wonchockier $R$ (2003). Percutaneous epididymal sperm aspiration (PESA) in men with obstructive azoospermia. Int Braz J Urol. 29(2):141-145; discussion 145-146.

3. Hồ Sỹ Hùng, Trân Thi Phương Mai (2013). Kết quả và các yế tố ảnh hưởng đến kỹ thuật tiêm tinh trùng vào bào tương noãn bằng tinh trùng lấy từ mào tinh. Tap chí Phu Sản. 11(2):139-142.

4. Trịnh Thi Ngọc Yến, Nguyến Mạnh Hà (2018). Đánh giá kết quả tiêm tinh trùng trích xuất vào bào tương noãn tại Bệnh viện Đại Học Y Hà Nội. Y hoc Viêt Nam. 471:114-118.

5. Shih K-W, Shen P-Y, Wu C-C,Kang Y-N
(2019). Testicular versus percutaneous epididymal sperm aspiration for patients with obstructive azoospermia: a systematic review and meta-analysis. Translational Andrology and Urology. 8(6):63140-63640.

6. Choudhary A (2013). Comparision of Intracytoplasmic Sperm Injection Outcomes Using Ejaculated Sperm and Retrieved Sperm. 4(6):3.

7. Esteves (2018). Use of testicular sperm for intracytoplasmic sperm injection in men with high sperm DNA fragmentation: a SWOT analysis.

8. Aboulghar $M$, Mansour $R$, Al-Inany $H$, et al (2007). Paternal age and outcome of intracytoplasmic sperm injection. Reprod Biomed Online. 14(5):588-592.

\title{
NHẬN XÉT KẾT QUẢ ĐIỀU TRỊ NGộ ĐộC CHÌ CẤP Ở TRẺ EM DO DÙNG “THUỐC CAM"
}

\section{Đinh Thị Hồng*, Lê Ngọc Duy*, Trương Thị Mai Hồng*}

\section{TÓM TẮT}

Mục tiêu: Nghiên cứu một số đặc điểm lâm sàng, cân lẩm sàng và đánh giá hiêu quả điều trị ngô độc chì ở trẻ em do sử dụng "thuốc cam". Đối tượng và phương pháp nghiên cứu: mô tả, cắt ngang trên 89 trẻ, tại Bệnh viện Nhi Trung ương, trong thời gian từ $6 / 2012$ đển $6 / 2021$. Kết quả: $60,7 \%$ trẻ dưới 1 tuổi; $47,2 \%$ trẻ được bôi vì tưa miêng. Triêu chứng lâm sàng: thay đổi tri giác $(40,4 \%)$, co giật $(48,3 \%)$, da xanh $(82 \%)$, nôn $(61,8 \%)$, tiêu chảy $(29,2 \%)$. Cận lâm sàng: $80 \%$ xquang có tăng cản quang đầu xương dài; giãn não thất $9,4 \%$; xuất hiên sóng đônng kinh trên điện não đồ $19,4 \%$. Dịch não tủy biến đổi với protein tăng cao $(1,64 \pm 1,36 \mathrm{~g} / \mathrm{l})$ trong khi tế bào bình thường hoăc tăng nhẹ $(9,8 \pm 24,89$ bạch cầu). Nồng độ chì máu trung bình lúc nhâp viện 108,39 \pm $55,8 \mu \mathrm{g} / \mathrm{dl}$. Sau 30 ngày điều trị nồng độ chì máu giảm $49,7 \%$, sau 1 năm giảm $71,3 \%$ và chì niêu đã tăng thải nhanh tại $T_{5}$ và $T_{30}$ với giá trị cao nhất là $5,664 \mathrm{mg} / \mathrm{l}$. Tỷ lệ tử vong là $6 / 89$ trẻ $(6,7 \%)$. Kết luận: Biểu hiện lẩm sàng của ngộ độc chì thường gặp là co giật, thay đổi tri giác và thiểu máu. Biến đối dịch não tủy theo kiểu protein tăng, tế bào bình thường. Nồng độ chì máu giảm dần và chì niệu tăng dần trong quá trình điều trị. Tỷ lệ tử vong là $6,7 \%$

Tư khóa: ngộ độc chì, thuốc cam.

\section{SUMMARY}

THE OUTCOMES OF MANAGEMENT OF ACUTE LEAD POISONING IN CHILDREN USING TRADITIONAL MEDICINE

Objectives: To investigate the clinical, sub-clinical

*Bệnh viện Nhi Trung ương

Chịu trách nhiêm chính: Đinh Thị Hồng

Email: dr.hong2909@gmail.com

Ngày nhận bài: 20.7.2021

Ngày phản biện khoa học: 8.9.2021

Ngày duyệt bài: 21.9.2021 features and the outcomes of management of acute lead poisoning in children using traditional medicine. Subjects and method: A descriptive cross sectional study to assess 89 patients in the NHP from June 2012 to June 2021 . Results: $60,7 \%$ of the participants are under 12 months old. $47,2 \%$ patients used traditional medicine for the treatment of fungi infection in the mouth. Common clinical features include mental status change $(40,4 \%)$, seizures $(48,3 \%)$, skin pallor $(82 \%)$ vomiting $(61,8 \%)$ and diarrhea $(29,2 \%)$. Sub-clinical features include: $80 \%$ of participants had increased mineral density of epiphysis, enlarge of ventricle $(9,4 \%) ; \quad 19,4 \%$ with epileptic waves in electroencephalogram. CSF changes in which protein elevates $(1,64 \pm 1,36 \mathrm{~g} / \mathrm{l})$ and cells were normal or mild increased $(9,8 \pm 24,89)$. The mean blood lead levels on admission is $108,39 \pm 55,8 \mu \mathrm{g} / \mathrm{dl}$. After 30 day of treatment, the blood lead levels decreased dramatically to $49,7 \%$ and to $71,3 \%$ after 1 year of treatment. Urine lead levels increased in day 5 and day 30 with the peak of $5,644 \mathrm{mg} / \mathrm{l}$. The mortality rate was of $6,7 \%$ (6/89 patients). Conclusion: Clinical presentation of children with lead poisoning included seizures and mental alternatives and anaemic. In the cerebrospinal fluid, proteins elevated but cells were unchanged. The blood lead levels decrease dramatically and urine lead levels gradually increased during treatment. The mortality rate was of $6,7 \%$

Keywords. lead poisoning, traditional medicine.

\section{I. ĐẶT VẤN ĐỀ}

Theo định nghĩa của Hiệp hội nhi khoa Hoa Kỳ, ngộ độc chì khi nồng độ chì trong máu(BLLBlood lead level) $\geq 10 \mu \mathrm{g} / \mathrm{dl}[1]$,[2]. Hội chứng não cấp như nôn, thay đổi hành vi, mất điều hòa, co giật, hôn mê thường chỉ xuất hiện trong ngộ độc chì nặng với $B L L \geq 70 \mu \mathrm{g} / \mathrm{dl}$ [3]. Hiện nay, người dân vẫn thường sử dụng "thuốc cam" không rõ nguồn gốc để chữa một số bênh của trẻ em như tưa lưỡi, loét miệng, tiêu chảy, biếng ăn do đó 
có thể gây ngộ độc chì cấp. Tại Việt Nam, các nghiên cứu về ngộ độc chì đặc biệt là trên bệnh nhi còn rất ít. Vì vậy chúng tôi tiển hành đề tài này với mục tiêu sau: Nghiên cứu một số đặc điểm lâm sàng, cận lâm sàng và đánh giá kết quả điều trị ngộ độc chì ở trẻ em do sử dụng "thuốc cam".

\section{II. ĐỐI TƯợNG VÀ PHƯƠNG PHÁP NGHIÊN CỨU \\ 2.1. Đối tượng nghiên cứu}

2.1.1. Tiêu chuẩn lựa chọn bệnh nhân: Tất cả trẻ $\leq 15$ tuổi, có tiển sử dùng thuốc cam, chì máu $\geq 10 \mu \mathrm{g} / \mathrm{dl}$

2.1.2. Tiêu chuẩn loại trừ: Trẻ có tiền sử động kinh, bại não hoặc rối loạn ý thức do nguyên nhân khác như viêm não - màng não...

2.2. Thời gian và địa điểm nghiên cứu: Từ 6/2012 đến 6/2021 tại Bệnh viện Nhi TW.

2.3. Phương pháp nghiên cứu: mô tả, cắt ngang.

\section{KẾT QUẢ NGHIÊN CỨU}

\section{1. Đặc điểm chung của đối tượng nghiên cứu}

Bảng 3.1. Đặc điểm về tuổi

\begin{tabular}{|c|c|c|}
\hline Nhóm tuối & $\mathbf{N}$ & $\mathbf{\%}$ \\
\hline$<6$ tháng & 25 & 28,1 \\
\hline $6-12$ tháng & 29 & 32,6 \\
\hline $1-6$ tuối & 31 & 34,8 \\
\hline$\geq 6$ tuối & 4 & 4,5 \\
\hline Tống & 89 & 100 \\
\hline $\begin{array}{c}\text { X } \pm \text { SD } \\
\text { (tháng tuổi) }\end{array}$ & \multicolumn{2}{|c|}{$\mathbf{1 4 . 1 9} \pm \mathbf{1 9 . 2 8}$} \\
\hline
\end{tabular}

Nhân xét: $60,7 \%$ trẻ dưới 1 tuối, trẻ nhỏ nhất là 1 tháng và lớn nhất là 108 tháng tuổi với tuổi trung bình là 14,19 $\pm 19,28$ tháng.

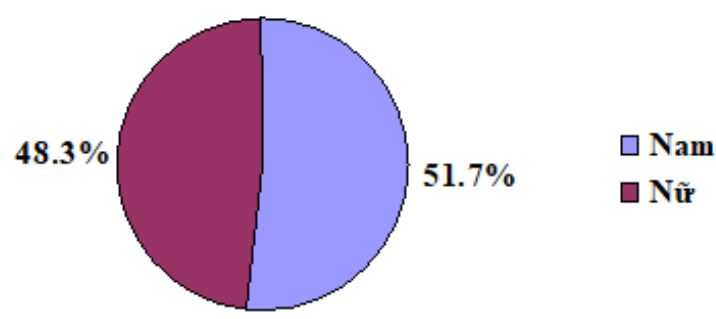

Biểu đồ 3.1. Đăc điểm về giới

Nhận xét: Tỷ lệ trẻ nữ là $43 / 89$ trẻ (chiếm $51,7 \%$ ) và nam là $46 / 89$ trẻ (chiếm $48,3 \%$ ). Tỷ lệ nam/nữ = 1/1,07.

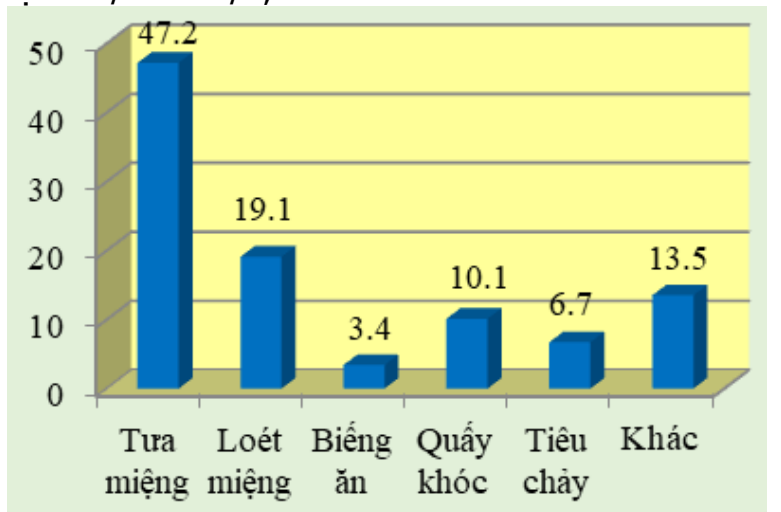

Biểu đồ 3.2. Lý do sử dụng thuốc Cam

Nhân xét: Lí do chủ yếu trẻ được sử dụng thuốc cam là do tưa miệng ( $42 / 89$ trẻ, chiếm $47,2 \%)$ và loét miệng (17/89 trẻ, chiếm 19,1\%). Còn lại là do một số nguyên nhân khác như quấy khóc, biếng ăn, tiêu chảy, chảy dãi, sẩn mặt, viêm $\mathrm{da}, \ldots$

\section{Bảng 3.2. Tình trạng cải thiện lâm sàng sau 5 ngày điều trị}

\begin{tabular}{|c|c|c|c|c|c|}
\hline \multirow{2}{*}{\multicolumn{2}{|c|}{ Triệu chứng }} & \multicolumn{2}{|c|}{ Lúc vào viện $(N=89)$} & \multicolumn{2}{|c|}{ Sau 5 ngày $(\mathrm{N}=83)$} \\
\hline & & $n$ & $\%$ & $n$ & $\%$ \\
\hline \multirow{4}{*}{$\begin{array}{l}\text { Rối } \\
\text { loạn ý } \\
\text { thức }\end{array}$} & Không (Glasgow 15 điếm) & 53 & 59,6 & 81 & 97,6 \\
\hline & Nhe (Glasgow 13 - 14 điếm) & 3 & 3,4 & 2 & 2,4 \\
\hline & Vừa (Glasgow 9 -12 điếm) & 26 & 29,2 & 0 & 0 \\
\hline & Nặng (Glasgow 3- 8 điếm) & 7 & 7,8 & 0 & 0 \\
\hline \multicolumn{2}{|r|}{ Co giât } & 43 & 48,3 & 2 & 2,4 \\
\hline \multicolumn{2}{|r|}{ Thóp phồng } & $11 / 57$ & 19,3 & 0 & 0 \\
\hline \multicolumn{2}{|r|}{ Nôn } & 55 & 61,8 & 3 & 3,6 \\
\hline \multicolumn{2}{|r|}{ Tiêu chảy } & 26 & 29,2 & 3 & 3,6 \\
\hline \multirow{3}{*}{$\begin{array}{l}\text { Suy hô } \\
\text { hấp }\end{array}$} & Không & 77 & 86,5 & 80 & 96,4 \\
\hline & Vừa & 3 & 3,4 & 3 & 3,6 \\
\hline & Nặng & 9 & 10,1 & 0 & 0 \\
\hline \multicolumn{2}{|r|}{ Da xanh } & 73 & 82,0 & 53 & 63,9 \\
\hline \multirow{2}{*}{\multicolumn{2}{|c|}{$\begin{array}{l}\text { Liệt dây TK ngoại biên } \\
\text { Không triêu chứng }\end{array}$}} & 1 & 1,1 & 1 & 1,2 \\
\hline & & 3 & 3,4 & 28 & 33,7 \\
\hline
\end{tabular}

Nhân xét: Sau 5 ngày điêu trị, có 6 trẻ tử vong, chỉ còn 83 trẻ. Lúc vào viện $40,4 \%$ trẻ có rối loạn trí giác đã giảm còn $2,4 \%$; trẻ bị co giật $4,3 \%$ giảm còn $2,4 \%$ ( 2 trẻ); thiếu máu $82 \%$ giảm còn $63,9 \% ; 3$ trẻ suy hô hấp nặng lúc vào đã cai được máy, chỉ còn thở oxy hố trợ. 
VIETNAM MEDICAL JOURNAL N01 - OCTOBER - 2021

Bảng 3.3. Kêt quả chẩn đoán hình ảnh

\begin{tabular}{|c|c|c|c|}
\hline \multicolumn{2}{|c|}{ CLS } & $\mathbf{n}$ & $\mathbf{\%}$ \\
\hline \multicolumn{2}{|c|}{ Điện não đồ có sóng ĐK } & $6 / 31$ & 19,4 \\
\hline \multirow{2}{*}{ XQ biến đối đâuu Xương dài } & $68 / 85$ & $\mathbf{8 0 , 0}$ \\
\hline \multirow{3}{*}{ CT/MRI sọ não } & Phù não & $2 / 32$ & 6,3 \\
\cline { 2 - 4 } & Giãn não thất & $3 / 32$ & 9,4 \\
\cline { 2 - 4 } & Không phát hiện gì & $27 / 32$ & 84,4 \\
\hline
\end{tabular}

Nhận xét: $80 \%$ bệnh nhân có viền tăng sáng ở các đâu dưới xương dài trên phim XQ. Chỉ có 6/31 trẻ được làm điện não đồ thấy xuất hiện sóng động kinh. Chụp CT/MRI sọ não có 3/32 (chiếm $9,4 \%)$ trẻ giãn não thất, $2 / 32(6,3 \%)$ trẻ có phù não.

Bảng 3.4. Biến đối dịch não tưy

\begin{tabular}{|c|c|c|c|c|}
\hline \multicolumn{2}{|c|}{ Chỉ số } & $\mathbf{n}$ & $\mathbf{\%}$ & $\mathbf{X} \pm$ SD \\
\cline { 2 - 4 } Tế bào & Bình thường & 24 & 68,6 & $9,8 \pm 24,89$ \\
& Tăng & 11 & 31,4 & $(0-135)$ \\
\hline \multirow{2}{*}{ Protein (g/l) } & Bình thường & 5 & 14,3 & $1,64 \pm 1,36$ \\
\cline { 2 - 4 } & Tăng & 30 & $\mathbf{8 5 , 7}$ & $(0.16-7.3)$ \\
\hline \multirow{2}{*}{ Glucose (mmol/I) } & Bình thường & 30 & 85,7 & $4.15 \pm 1.49$ \\
\cline { 2 - 4 } & Giảm & 5 & 14,3 & $(0.31-7.7)$ \\
\hline
\end{tabular}

Nhận xét: 35 bênh nhân được chọc dịch não tủy và đều có biến đối dịch não tủy với nồng đô Protein tăng cao $(85,7 \%)$ trong khi tế bào có thể bình thường $(68,6 \%)$ hoặc tăng nhẹ và nồng độ glucose bình thường $(85,7 \%)$.

\section{4 Đánh giá kết quả điêu trị}

Bảng 3.5. Sự biến đổi nồng độ chi máu và chi niệu trong thời gian điều trị

\begin{tabular}{|c|c|c|c|}
\hline & & Chì máu ( $\mu \mathrm{g} / \mathrm{dl})$ & Chì niệu(mg/l) \\
\hline \multirow{2}{*}{ To } & $\mathbf{n}$ & \multicolumn{2}{|l|}{ (2.ing } \\
\hline & $\mathbf{X} \pm \mathbf{S D}($ Min - Max) & $108,37 \pm 55,80(34,60-384,20)$ & $0,712 \pm 0,539(0,002-2,522)$ \\
\hline \multirow{4}{*}{$\mathbf{T}_{5}$} & $\mathrm{n}$ & \multicolumn{2}{|l|}{83} \\
\hline & $\mathbf{X} \pm \mathbf{S D}($ Min - Max) & $73,75 \pm 36,67(32,50-248,40)$ & $1,298 \pm 0,783(0,047-5,037)$ \\
\hline & Sự thay đối (\%) & $33,11 \pm 31,97(30,6 \%)$ & $0,586 \pm 0.702(82,3 \%)$ \\
\hline & $\mathrm{p}$ & 0,000 & 0,000 \\
\hline \multirow{4}{*}{$\mathbf{T}_{30}$} & $n$ & \multicolumn{2}{|c|}{83} \\
\hline & $\mathbf{X} \pm \mathbf{S D}(\operatorname{Min}-\operatorname{Max})$ & $52,94 \pm 18,12(22,7-155,28)$ & $1,408 \pm 0.808(0,023-5.664)$ \\
\hline & Sự thay đối (\%) & $53,91 \pm 55,74(49,7 \%)$ & $0,680 \pm 0,857(95,5 \%)$ \\
\hline & $p$ & 0,000 & 0,000 \\
\hline \multirow{4}{*}{ T90 } & $n$ & \multicolumn{2}{|c|}{78} \\
\hline & $\mathbf{X} \pm \mathbf{S D}(\operatorname{Min}-\operatorname{Max})$ & $50,13 \pm 24,02(20,20-215,50)$ & $0,463 \pm 0,413(0,024-1,898)$ \\
\hline & Sự thay đổi (\%) & $57,70 \pm 55,67(53,2 \%)$ & $0,280 \pm 0,509(39,3 \%)$ \\
\hline & $\mathrm{p}$ & 0,000 & 0,000 \\
\hline \multirow{4}{*}{$\mathbf{T}_{180}$} & $\mathrm{n}$ & \multicolumn{2}{|c|}{70} \\
\hline & $\mathbf{X} \pm \mathbf{S D}($ Min - Max) & $40,55 \pm 9,14(18,20-68,70)$ & $0,291 \pm 0,304(0,017-1,205)$ \\
\hline & Sự thay đối (\%) & $69,10 \pm 56,13(63,8 \%)$ & $0,475 \pm 0,525(66,7 \%)$ \\
\hline & $\mathrm{p}$ & 0,000 & 0,000 \\
\hline \multirow{4}{*}{ T1năm } & $n$ & \multicolumn{2}{|c|}{67} \\
\hline & $\mathbf{X} \pm \mathbf{S D}($ Min - Max) & $33,13 \pm 7,80(19,50-63,20)$ & $0,112 \pm 0,159(0,010-0,815)$ \\
\hline & Sự thay đối (\%) & $77,28 \pm 56,94(71,3 \%)$ & $0,680 \pm 0,508(95,5 \%)$ \\
\hline & $p$ & 0,000 & 0,000 \\
\hline
\end{tabular}

Nhận xét: Nồng độ chì máu trung bình của đối tượng nghiên cứu giảm dần theo thời gian điều trị, đặc biệt sau 30 ngày điều trị nồng độ chì máu đã giảm được 49,7\%. Nồng độ chì niệu tăng nhanh sau gắp chì tại $T_{5}$ và $T_{30}$ với giá trị cao nhất là $5,664 \mathrm{mg} / \mathrm{l}$.

\begin{tabular}{|c|c|c|c|c|c|}
\hline \multicolumn{2}{|c|}{ Mức độ nặng } & Nhẹ & Trung bình & Nặng & $\mathbf{p}$ \\
\hline$T_{0}$ & $\mathrm{n}(\%)$ & $2(2,2)$ & $17(19,1)$ & $70(78,7)$ & \multirow{2}{*}{0,000} \\
\hline 10 & $X \pm S D$ & $39,35 \pm 6,72$ & $58,64 \pm 7,73$ & $122,42 \pm 54,85$ & \\
\hline$T_{5}$ & $\mathrm{n}(\%)$ & $11(13,3)$ & $35(42,2)$ & $37(44,6)$ & 0,001 \\
\hline
\end{tabular}




\begin{tabular}{|c|c|c|c|c|c|}
\hline & $X \pm S D$ & $40,17 \pm 4,27$ & $55,50 \pm 6,86$ & $100,99 \pm 39,78$ & \\
\hline \multirow{2}{*}{$\mathbf{T}_{30}$} & $\mathrm{n}(\%)$ & $28(33,7)$ & $46(55,4)$ & $9(10,8)$ & \multirow{2}{*}{0,000} \\
\hline & $X \pm S D$ & $38,08 \pm 5,74$ & $54,62 \pm 5,34$ & $90,59 \pm 26,68$ & \\
\hline \multirow{2}{*}{ T90 } & $\mathrm{n}(\%)$ & $34(43,6)$ & $38(48,7)$ & $6(7,7)$ & \multirow{2}{*}{0,000} \\
\hline & $X \pm S D$ & $35,10 \pm 5,74$ & $55,07 \pm 6,65$ & $104,07 \pm 55,91$ & \\
\hline \multirow{2}{*}{$\mathbf{T}_{180}$} & $\mathrm{n}(\%)$ & $47(67,1)$ & $23(32,9)$ & 0 & \multirow{2}{*}{0,004} \\
\hline & $X \pm S D$ & $35,70 \pm 6,18$ & $50,46 \pm 5,41$ & & \\
\hline \multirow[b]{2}{*}{ T1năm } & $\mathrm{n}(\%)$ & $66(98,5)$ & $1(1,5)$ & 0 & \multirow{2}{*}{0,000} \\
\hline & $X \pm S D$ & $32,68 \pm 6,90$ & 63,2 & & \\
\hline
\end{tabular}

Nhận xét: mức độ nặng của bệnh đã được giảm dần, tại thời điếm 180 ngày điều trị, chỉ còn bệnh nhân ở mức độ nhẹ và trung bình. Sau 1 năm theo dối chỉ có 1 bệnh nhân ở mức độ trung bình với nồng độ chì máu $63,2 \mu \mathrm{g} / \mathrm{dl}$, còn lại 66 trẻ mức độ nhẹ.

Bảng 3.7. Nguyên nhân tử vong

\begin{tabular}{|c|c|c|c|c|c|}
\hline Nguyên nhân & Tăng ALNS dai dắng & Hôn mê sâu & Suy đa tạng & $\mathbf{n}$ & \% \\
\hline Tỹ lệ tử vong & 1 & 6 & 3 & 6 & 6,7 \\
\hline
\end{tabular}

Nhận xét: Tỷ lệ tử vong của ngộ độc chì là 6,7\% (6/89 trẻ) đa số là do hôn mê sâu. Có 1 trẻ tăng áp nội sọ dai dẳng. Có 3 trẻ suy đa tạng (suy hô hấp, suy tuần hoàn, suy gan, rối loạn đông máu).

\section{BÀN LUÂNN}

4.1. Đặc điểm chung của đối tượng nghiên cứu

* Tuổi: Trong nghiên cứu của chúng tôi $60,7 \%$ trẻ dưới 1 tuổi với tuổi trung bình là $14,19 \pm 19,28$ tháng. Kết quả này tương tự như nghiên cứu của Ngố Tiến Đông (2011) (trẻ dưới 1 tuổi chiếm 66\%) [4], nhưng tuổi trung bình lại thấp hơn của Nguyển Anh Tuấn và cộng sự (2013) nghiên cứu 67 trẻ, tuổi trung bình là 26,9 土24,9 tháng (từ 4 tháng đến 10 tuổi) [5]. Đây là lứa tuổi hay có những cơn quấy khóc không rõ nguyên nhân, đồng thời trẻ cũng bắt đầu gặp các bệnh liên quan đến tiêu hóa thường gặp như tưa lưỡi, loét miệng, tiêu chảy...Đó là những lí do mà cha mẹ dùng thuốc cam cho trẻ.

* Giới: Trong nghiên cứu của chúng tôi tỷ lệ trẻ nam/nữ là $1 / 1,07$ khác với nghiên cứu của Ngô Việt Hưng (2013) [6] trên 108 bệnh nhân thì tỷ lệ nam/nữ là $1,2 / 1$, có thể là do đối tượng nghiên cứu của chúng tôi là trẻ ngộ độc chì do thuốc cam.

* Lí do dùng thuốc: Trẻ được sử dụng thuốc cam chủ yếu do tưa miệng $(47,2 \%)$ và loét miệng $(19,1 \%)$. Kết quả này cũng tương tự như của Ngô Tiến Đông và cộng sự (2011), 40\% trẻ được dùng thuốc cam điều trị tưa miệng.

4.2. Đặc điểm lâm sàng và cận lâm sàng

- Lâm sàng: $40,4 \%$ trẻ có thay đổi tri giác ở các mức độ (đa phần là mức độ vừa), 53/89 trẻ $(59,6 \%)$ tỉnh táo. Phần lớn trẻ có ít nhất 1 lần co giật (48,3\%). Biều hiện co giật trong ngộ độc chì là co giật toàn thân. Theo tác giả Ngô Việt Hưng [5], biểu hiện trên hệ thần kinh thường gặp là co giật, li bì, dễ kích thích, liệt dây thần kinh sọ, trong đó co giật chiếm tỷ lệ cao nhất $(83,9 \%)$, tiếp theo là dễ kích thích 6,5\%, li bì 6,5\% và liệt dây thần kinh sọ 3,2\%. Triệu chứng thóp phồng chỉ gặp ở 11/57 trẻ còn thóp trước. Những trẻ này khi đển viện thường kèm dấu hiệu mất nước do nôn, tiêu chảy, ăn kém, nên triệu chứng thóp phồng ít nhiều bị ảnh hưởng. Trong nghiên cứu, chúng tôi gặp 1 ca bệnh có liệt thần kinh ngoại biên, gây yếu 2 chi dưới.

Dấu hiệu lâm sàng trên hệ tiêu hóa thường gặp bao gồm nôn chiếm $61,8 \%$, tiêu chảy chiếm $29,2 \%$. So sánh với tác giả Ngô Tiến Đông (2011) [3], nôn gặp ít hơn (21,3\%), và tiêu chảy chỉ $4,6 \%$. Điều này có thể do dấu hiệu nôn là biểu hiện của rối loạn tiêu hóa nhưng cũng có thể là biểu hiện của tăng áp lực nội sọ ở trẻ.

Trong nghiên cứu có $12 / 89$ trẻ bị suy hô hấp, trong đó 3 trẻ bị suy hô hấp nhẹ hoặc trung bình, cần hỗ trợ oxy mask, 9 trẻ bị suy hô hấp nă̆ng đòi hỏi phải đặt nội khí quản và thở máy hố trợ. Những trẻ này có biểu hiện phù não nặng, gây ức chế trung tâm hô hấp.

* Cận lâm sàng: $80 \%$ trẻ có viền tăng sáng ở đầu dưới xương dài trên phim Xquang. Kết quả này cũng tương tự như của Ngô Việt Hưng (100\% bệnh nhân). Chúng tôi chỉ phát hiện 19,4\% trường hợp xuất hiện sóng động kinh trên điện não đồ, trong khi nghiên cứu của Ngô Việt Hưng là 30,3\%. Có thể do cõ mẫu của chúng tôi còn nhỏ. Hầu hết bệnh nhân có biến đổi dịch não tủy với nồng độ protein tăng cao $(85,7 \%)$ trong khi số lượng tế bào bình thường hoặc tăng nhẹ. Đây chính là lý do bệnh chì não dễ bị chẩn đoán nhầm với viêm màng não mủ mất đầu hay viêm màng não do lao.

4.3. Kết quả điêu trị. Trong quá trình theo dõi, có 6 trẻ tử vong trong vòng 5 ngày sau vào 
viện (chiếm 6,7\%). Đánh giá sau 5 ngày điều trị, $40,4 \%$ trẻ có rối loạn tri giác lúc vào giảm còn $2,4 \%$, trẻ bị co giật $4,3 \%$ giảm còn $2,4 \%$ ( 2 trẻ); thiếu máu $82 \%$ giảm còn $63,9 \% ; 3$ trẻ suy hô hấp năng lúc vào đã cai được máy, chỉ còn thở oxy hố trợ.

Kết quả cho thấy nồng độ chì máu đã giảm dần trong quá trình điều trị. Sau 5 ngày, nồng độ

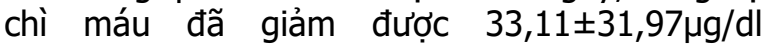
$(30,6 \%)$ và chì niệu đã tăng thải được $0,586 \pm$ $0.702(82,3 \%)$. Kểt quả này tương tự với nghiên cứu của Nguyễn Anh Tuấn trên 67 bệnh nhân được điều trị bằng EDTA với liều $25 \mathrm{mg} / \mathrm{kg} / \mathrm{ngày}$, nồng độ chì máu giảm trung bình $14,08 \mu \mathrm{g} / \mathrm{dl}$ $(27,22 \%)$, chì niệu trung bình $0,59 \pm 0,38$. Đặc biệt sau 30 ngày điều trị nồng độ chì máu đã giảm được 49,7\%, sau 1 năm giảm $71,3 \%$. Mức độ nặng của bệnh đã được giảm dần, tại thời điểm 90 ngày điều trị, chỉ còn bệnh nhân ở mức độ nhe và trung bình. Sau 1 nằm theo dõi chỉ còn 1 bệnh nhân ở mức độ trung bình với nồng độ chì máu 63,2 $\mu \mathrm{g} / \mathrm{dl}[6]$.

\section{KẾT LUÂNN}

Biểu hiện lâm sàng của ngộ độc chì cấp ở trẻ em chủ yếu là co giật và thay đổi tri giác, da xanh. Biểu hiện cận lầm sàng đặc trưng bởi biến đổi dịch não tủy theo kiểu protein tăng, tế bào bình thường, có thể thấy sóng động kinh trên điện não đồ. Nếu được chẩn đoán và điều trị sớm thì hiệu quả tương đối tốt, giảm tỷ lệ tử vong.

\section{TÀI LIÊU THAM KHẢO}

1. American Academy of Pediatric Committee on Environmental Health (2005), "Lead exposure in children: prevent, detection, and management", Pediatric; 116; 1036.

2. Bô Y Yế (2012), "Hướng dẫn chẩn đoán và điều trị ngộ độc chi".' (Ban hành kèm theo Quyết định số 1548/QQĐ-BYT ngày 10 tháng 5 năm 2012 của Bộ trưởng Bộ Y tế). chủ biên.

3. Centers for Disease Control and Prevention (CDC) (2005), "Blood lead levels-United States, 1999-2002", MMWR Morb Mortal Wkly Rep, 54:513.

4. Ngô Tiến Đông, Pham Thi Vân Anh, Pham Vắn Thắng (2012), "Ngộ độc chì ở trẻ em liên quan đến sử dụng thuốc nam: một số đặc điểm dịch tể, lâm sàng, cân lâm sàng và nhận xét kết quả điệu trị", Tạp chí y học.

5. Nguyển Anh Tuấn, Phàm Duế, Bế Hông Thu và cộng sự (2013), "Nhận xét hiệu quả bước đầu điều trị Ngộ độc chì ở trẻ em bắng EDTA tại trung tâm chống độc bênh viên Bach Mai 20122013",Kỷ yếu hội nghị chống độc quốc tế Hà Nội 2013:113- 25

6. Ngô Việt Hưng (2013), "Nghiên cứu đặc điểm lâm sàng, cận lâm sàng ngộ độc chì ở trẻ em điều trị tại Trung tâm chống độc Bạch Mai", Luận văn thạc sỹ, Đại học Y Hà Nội.

\section{NGUYÊN NHÂN PHẢN VÊ VÀ ĐĂC ĐIỂM LÂM SÀNG THEO NGUYÊN NHÂN Ở TRẺ EM TẠI BỆNH VIỆN NHI TRUNG ƯO'NG (2017-2021)}

\section{Đinh Thị Thu Phương*, Lê Ngọc Duy*, Trương Thị Mai Hồng*}

\section{TÓM TẮT}

Muc tiêu: Mô tả nguyên nhân phản vê và đăc điểm lầm sàng theo nhóm nguyên nhân tại Bệnh việ̉n Nhi Trung ương. Đối tượng và phướng pháp: nghiên cứu mô tả cắt ngang 129 trẻ phản vệ tại Bệnh viên Nhi Trung ương tữ tháng $1 / 2017$ đến i/2021. Kết quả: $63,6 \%$ trẻ dưới 1 tuổi; tỷ lệ nam/nữ: 1,4/1, trong đó $64,3 \%$ người bệnh được chuyển lên từ các cơ sở y tế. Thuốc là nguyên nhân gây phản vệ cao nhất: $62,8 \%$, vắc xin: $18,6 \%$, thức ăn: $14 \%$, côn trùng đốt 3,9\%... Các triệu chứng lâm sàng của phản vê đa dạng theo nhóm nguyên nhân: do thuốc biểu hiên ở tuân hoàn $(91 \%)$ và thần kinh $(88 \%)$; do vắc xin biểu hiện ở hệ tuần hoàn $(92 \%)$, thần kinh $(96 \%)$; do thức ăn và côn trùng biểu hiện nhiều ở da và niêm

*Bệnh viện Nhi Trung ương

Chịu trách nhiệm chính: Đinh Thị Thu Phương

Email: dinhphuonghmu@gmail.com

Ngày nhận bài: 19.7.2021

Ngày phản biện khoa họ: 7.9.2021

Ngày duyệt bài: 20.9.2021 mạc $(100 \% ; 100 \%)$. Căn nguyên thuốc và vắc xin thường gây phản về mức đô năng, đô 3 (64,2\%; $54,2 \%)$ và độ $4(12,3 \% ; 8,3 \%)$. Kết luận: Thuốc là nguyên nhân gây phản vệ chủ yếu. Phản vệ do thuốc và vắc xin biểu hiện triệu chứng nhiều ở hệ tuân hoàn, thần kinh và thường ở mức độ năng. Phản vê do thức ăn và côn trùng chủ yếu gây triệu chứng ở niểm mạc.

Tư khóa: phản vệ, triệu chứng, trẻ em

\section{SUMMARY}

\section{CLINICAL CHARACTERISTICS BY CAUSE OF} ANAPHYLAXIS IN CHILDREN AT VIET NAM NATIONAL CHILDREN'S HOSPITAL (2017-2021)

Objectives: Trigger of anaphylaxis and characteristic symptoms for each trigger in children at Vietnam National Children's Hospital. Method: A cross-sectional descriptive study was recorded 129 patients at Vietnam National Children's Hospital from January 2017 to July 2021. Results: $63,6 \%$ of the participants are under 12 months old. The ratio of boy-girl is $1.4 / 1 ; 64.3 \%$ of patients were transferred from medical facilities. Drugs are the most common trigger of anaphylaxis $62.8 \%$, vaccines: $18,6 \%$, food: 